\title{
Hot isostatic pressing of potassium-magnesium-phosphate materials for cesium immobilization
}

\author{
S.Y.Sayenko, V.A.Shkuropatenko, G.O.Kholomeev, \\ O.V.Pylypenko, A.V.Zykova, M.M.Belash, R.V.Tarasov, \\ O.Y.Surkov, E.A.Ulybkina, K.V.Lobach, M.Sawczak ${ }^{2}$, M.Kmiec $^{3}$ \\ ${ }^{1}$ NSC "Kharkov Institute Physics and Technology", \\ 1, Akademicheskaya St., Kharkov, 61108, Ukraine \\ ${ }^{2}$ Institute of Fluid-Flow Machinery Polish Academy of Science, \\ 14 J.Fiszera St., 80-952 Gdansk, Poland \\ ${ }^{3}$ Gdansk University of Technology, G.Narutowicza 11/12, \\ 80-233 Gdansk, Poland
}

Received September 17, 2017

\begin{abstract}
High-density potassium-magnesium phosphates (PMP), produced by hot isostatic pressing (HIP) at temperature of $900^{\circ} \mathrm{C}$ and pressures of 200 and $400 \mathrm{MPa}$, are promising materials for the immobilization of radioactive cesium. The maximum density of PMP samples was obtained after HIP at pressure of $400 \mathrm{MPa}, 900^{\circ} \mathrm{C}$ and holding time of $1 \mathrm{~h}$, and $\mathrm{PMP}+10$ wt. $\% \mathrm{CsCl}$ samples at $200 \mathrm{MPa}, 900^{\circ} \mathrm{C}$ and $1 \mathrm{~h}$. The resulted materials possess monophase monoclinic structure of potassium-magnesium monophosphate $\alpha$ $\mathrm{KMgPO}_{4}$. The possibility of PMP materials to incorporate cesium into its structure by substitution with potassium has been studied by X-ray phase analysis and laser mass spectrometry methods using. The homogeneous fine-crystalline structure of ceramic PMP and PMP + 10 wt. $\% \mathrm{CsCl}$ samples after HIP was analyzed by scanning electron microscopy method.

Keywords: potassium-magnesium phosphate, cesium, hot isostatic pressing, X-ray phase analysis, electron microscopy, density.
\end{abstract}

Высокоплотные калий-магниевые фосфаты (КМФ), полученные горячим изостатическим прессованием (ГИП) при температуре $900^{\circ} \mathrm{C}$ и давлении 200 и 400 МПа, являются перспективными материалами для иммобилизации радиоактивного цезия. Максимальная плотность КМФ образцов получена после ГИП при давлении 400 МПа, температуре $900^{\circ} \mathrm{C}$ и времени выдержки 1 час, а $\mathrm{KM} \Phi+10$ вес.\% $\mathrm{CsCl}$ образцов - при давлении $200 \mathrm{MПа,} \mathrm{температуре} 900^{\circ} \mathrm{C}$ и времени выдержки 1 час. Полученные материалы обладают монофазной моноклинной структурой калий-магниевого монофосфата $\alpha-\mathrm{KMgPO}_{4}$. Методами рентгеновского фазового анализа и лазерной масс-спектрометрии изучена возможность КМФ материалов по включению в свою структуру цезия путем замещения им калия. Показано методами сканирующей электронной микроскопии, что керамические КМФ и КМФ + 10 вес.\% CsCl образцы после ГИПа обладают однородной мелкокристаллической структурой.

Гаряче ізостатичне пресування калій-магній-фосфатних матеріалів для іммобілізації цезію. С.Ю.Саєнко, В.А.ШКуропатенко, Г.О.Хололєєв, О.В.Пилипенко, Г.В.Зикова, Н.Н.Бєлаш, Р.В.Тарасов, О.є.Сурков, К.А.Улибкіна, К.В.Лобач, М.Савчак, М.Кліец.

Високощільні калій-магнієві фосфати (КМФ), отримані гарячим ізостатичним пресуванням (ГІП) при температурі $900^{\circ} \mathrm{C}$ і тиску 200 і $400 \mathrm{MПа,} \mathrm{є} \mathrm{перспективними}$ 
матеріалами для іммобілізації радіоактивного цезію. Максимальна щільність КМФ зразків отримана після ГІП при тиску $400 \mathrm{MПа,} \mathrm{температурі} 900^{\circ} \mathrm{C}$ і часу витримки 1 година, а КМФ + 10 ваг. \% CsCl зразків - при тиску $200 \mathrm{MПа,} \mathrm{температурі} 900^{\circ} \mathrm{C}$ i часу витримки 1 година. Отримані матеріали мають монофазну моноклінну структуру калій-магнієвого монофосфата $\alpha-\mathrm{KMgPO}_{4}$. Методами рентгенівського фазового аналізу $\mathrm{i}$ лазерної мас-спектрометрії вивчено можливість КМФ матеріалів з включення в свою структуру цезію шляхом заміщення ним калію. Показано методами скануючої електронної мікроскопії, що керамічні КМФ і КМФ + 10 ваг.\% CsCl зразки після ГІПа володіють однорідною дрібнокристалічною структурою.

\section{Introduction}

Reliability of radionuclides immobilization into the matrices should be guaranteed by a complex of physical and chemical properties of the matrices [1]. The mechanical characteristics of the resulting matrices material have significant influence on the safety of the radionuclides disposal. The matrices containing radionuclides are exposed to different mechanical loads during processes of producing, storage, transportation, and immobilization into the geological environment. The insufficient mechanical properties (compressive strength, bending, etc.) of the matrices materials result in appearance of cracks and fractures of cured radioactive waste (RAW) and, as a consequence, to decrease of material chemical resistance [2]. High density of ceramic materials is one of the most important factors ensuring high mechanical properties. Simultaneously with the increase in density, the mechanical properties and thermal stability of ceramics are improved, and the rate of chemical reactions on the surfaces (dissolution, interaction with salt solutions) is decreased by reducing the specific surface [3].

The most famous methods for producing of high-density ceramic materials for RAW immobilization are cold pressing followed by sintering, hot pressing or hot isostatic pressing (HIP). To obtain high-density ceramic matrices by sintering in air, in a vacuum or an inert medium, higher processing temperatures and longer holding times are required. This process leads to the liberation of readily volatile radio nuclides from the matrices, and cesium in particular. The application of the hot pressing method in vacuum allows not only to achieve a reduction in the synthesis temperature and a decrease in the heat treatment time, but also to produce high density samples of the material. However, the process of hot pressing involves the use of graphite molds and the pressed material will inevitably be in a medium saturated with carbon. As is known, carbon is able to enter into the phosphates structure resulting in a degradation of crys- tallinity, increased solubility and decrease in the thermal stability [4]. Therefore, the application of the method of hot isostatic pressing, providing a high density of the pressed material and avoiding abovementioned disadvantages is fully justified.

Examples of the production by means of HIP method (temperature $\sim 850^{\circ} \mathrm{C}$, pressure $100 \mathrm{MPa}$ ) of sodalite-containing glass forms for the immobilising fission product-bearing waste $\mathrm{KCl}-\mathrm{LiCl}$ pyroprocessing salts in the ANSTO (Australian Nuclear Science and Technology Organization) are known. The obtained samples were characterized by high density and showed high corrosion resistance in the process of conducting leaching tests in water [5].

There is an experience of successful application of the process of hot isostatic pressing for manufacture of mineral-like ceramic matrices of Synroc composition for high-level waste immobilization in NSC KIPT. This experience was used in the development of glass-ceramic mineral-like materials of aluminosilicate composition for application as protective elements in the encapsulation of spent nuclear fuel (SNF) [6].

Recently, potassium-magnesium phosphate $\mathrm{KMgPO}_{4} \cdot 6 \mathrm{H}_{2} \mathrm{O}$ (PMP), which has a room temperature of synthesis, high corrosion properties and radiation resistance, is proposed for the immobilization of both separately isolated radionuclides and liquid radioactive wastes [7-10]. Its anhydrous form $\mathrm{KMgPO}_{4}$ is of interest as an inorganic compound that can reliably hold the ${ }^{137} \mathrm{Cs}$ radioactive isotope and be used as a source of gamma radiation for medical purposes such as cancer treatment and diagnosis of heart disease. In addition, such a form of sources after the end of the service life allows to be stored without additional processing.

The aim of the paper was to study the hot isostatic pressing method for production of a high-density fine-grained ceramics based on potassium magnesium phosphate $\mathrm{KMgPO}_{4}$ needed for immobilization of radioactive cesium. 

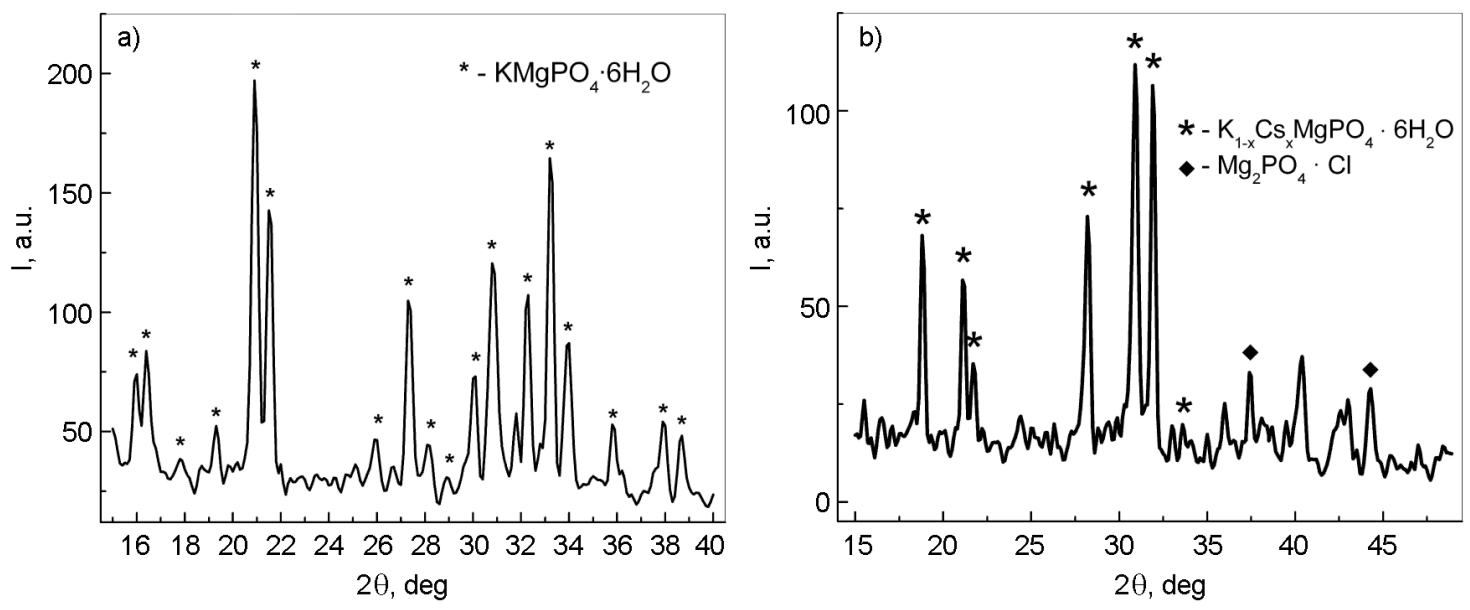

Fig. 1. XRD patterns of the samples: a - PMP, b - PMP +10 wt. \% CsCl.

\section{Experimental}

Hot isostatic pressing of PMP samples was carried out at NSC KIPT on a laboratory HIP installation GAUS-4/2000-35. The operating parameters of the installation are following: working gas - argon, maximum pressure - $400 \mathrm{MPa}$, maximum temperature $-2000^{\circ} \mathrm{C}$. The dimensions of insidefurnace space were following: diameter $35 \mathrm{~mm}$, height $170 \mathrm{~mm}$. The gas pressure (up to $400 \mathrm{MPa}$ ) in the unit is created by the cryogenic thermocompressor KRIT-4L, which was designed and manufactured at the NSC KIPT.

Preliminary heat treatment of potassium-magnesium-phosphate samples was carried out in air at $700^{\circ} \mathrm{C}$ for $1 \mathrm{~h}$ in a Nabertherm L5/13/B180 (Germany) furnace.

The phase composition of the PMP materials was studied by X-ray diffraction analysis (XRD) (DRON-4-07 in copper Cu$\mathrm{K} \alpha$ radiation using a $\mathrm{Ni}$ selectively absorbing filter). The ASTM diffraction data base was used to identify the obtained phases.

Elemental analysis of PMP samples with the addition of 10 wt. $\% \mathrm{CsCl}$ was performed on a high-resolution laser mass spectrometer EMAL-2.

To determine the processes occurring during the heating of the PMP samples, a differential thermal and thermo-gravimetric analysis (DTA/TG) was performed on the SDT Q600 thermal analyzer in the temperature range $(20-1300)^{\circ} \mathrm{C}$ at a heating rate of $10^{\circ} \mathrm{C} / \mathrm{min}$.

A study of the structure of the obtained ceramic materials and X-ray spectrometric measurements of the composition was carried out on a scanning electron microscope Zeiss EVO 40 and JEM-7001 F equipped with an X-ray EDX microanalyzer PentaFET-x3 (Oxford INCA) at an accelerating voltage of $20 \mathrm{kV}$. X-ray spectra were processed using Oxford Instruments INCA 4.11.

Raman spectra were obtained on the Raman spectroscopy scientific equipment "Renishaw in Via". 3D tomography was performed on 3D XRD Tomography (Phoenix micromex DXR-HD, GE Sensing \& Inspection Technologies GmbH, Germany).

The density of the samples after HIP was determined by hydrostatic weighing.

The synthesis of potassium-magnesium phosphate $\mathrm{KMgPO}_{4} \cdot 6 \mathrm{H}_{2} \mathrm{O}$ was carried out at room temperature using the following reagents:

- magnesium oxide $\mathrm{MgO}$;

- potassium dihydrogen phosphate $\mathrm{KH}_{2} \mathrm{PO}_{4}$

- distilled water.

PMP was produced as a result of an acidalkaline reaction between $\mathrm{MgO}$ and $\mathrm{KH}_{2} \mathrm{PO}_{4}$ in water [7]:

$$
\begin{gathered}
\mathrm{MgO}+\mathrm{KH}_{2} \mathrm{PO}_{4}+5 \mathrm{H}_{2} \mathrm{O}= \\
=\mathrm{KMgPO}_{4} \cdot 6 \mathrm{H}_{2} \mathrm{O} .
\end{gathered}
$$

The simulator of radioisotopes ${ }^{137} \mathrm{Cs}$ and ${ }^{134} \mathrm{Cs}$ in the synthesis of cesium-containing PMP samples was $\mathrm{Cs}^{+}$, which was introduced as cesium chloride $\mathrm{CsCl}$.

The PMP phase composition studies by $\mathrm{X}$-ray phase analysis (XRD) showed that the PMP samples, both containing cesium and without cesium, mainly consist of hexahydrate of potassium and magnesium double orthophosphate $\mathrm{KMgPO}_{4} \cdot 6 \mathrm{H}_{2} \mathrm{O}$ of rhombohedral structure (ASTM 35-0812) (Fig. 1a, b). On the diffractogram of the PMP sample + 10 wt. $\% \mathrm{CsCl}$ there were also lines of magnesium chloride phosphate $\mathrm{Mg}_{2} \mathrm{PO}_{4} \mathrm{Cl}$ (Fig. 1b). 
After adding of 10 wt. $\% \mathrm{CsCl}$, a small shift of the main X-ray lines $\mathrm{KMgPO}_{4} \cdot 6 \mathrm{H}_{2} \mathrm{O}$ toward smaller angles was observed. The shift is explained by the partial substitution of potassium atoms by cesium atoms with large ionic radii. According to this fact, the obtained material of PMP samples with cesium (90 wt. \% PMP $+10 \mathrm{wt} \% \mathrm{CsCl}$ ) can be represented as $\mathrm{K}_{1-x} \mathrm{Cs}_{x} \mathrm{MgPO}_{4} \cdot 6 \mathrm{H}_{2} \mathrm{O}$.

In the HIP technology, cylindrical capsules are usually made of stainless steel with a thickness of a few tenths of a millimeter. To avoid excessive deformation of the resulting blanks in order to increase the density of the feed material before the process of HIP, preliminary sintering of the initial powders in air is necessary [6]. In the case of potassium-magnesium phosphate, which contains bound water, preliminary heat treatment is also necessary to remove water. As is known, in the process of heat treatment dehydration of potassium-magnesium phosphate occurs in accordance with the following reaction [11]:

$$
\mathrm{KMgPO}_{4} \cdot 6 \mathrm{H}_{2} \mathrm{O} \rightarrow \mathrm{KMgPQ}_{4}+6 \mathrm{H}_{2} \mathrm{O} \text {. }
$$

Using DTA/TG analysis, it was found that the endothermic peak at a temperature of $120^{\circ} \mathrm{C}$ corresponds to the dehydration of the PMP sample (Fig. 2a). This fact is confirmed by a weight loss $(\sim 40 \%)$ on the TG curve, which corresponds to the removal of the stoichiometric amount of bound water. Above the temperature of $\sim 250^{\circ} \mathrm{C}$, the weight of the PMP sample does not change. In contrast to the PMP sample, a weight loss of $~ 30 \%$ of the PMP sample with the addition of cesium chloride up to a temperature of $700^{\circ} \mathrm{C}$ is observed (Fig. 2b). Above the temperature of $700^{\circ} \mathrm{C}$, the sample weight practically does not change. Therefore, in order to avoid the removal of water or gas release in the process of HIP, the thermal treatment of PMP samples with both cesium chloride addition and without additives at temperature of $700^{\circ} \mathrm{C}$ for $1 \mathrm{~h}$ was carried out. After heat treatment, an elemental analysis of the PMP samples with the addition of $10 \mathrm{wt} . \% \mathrm{CsCl}$ was carried out on an EMAL-2 laser mass spectrometer. The results of elemental analysis of PMP +
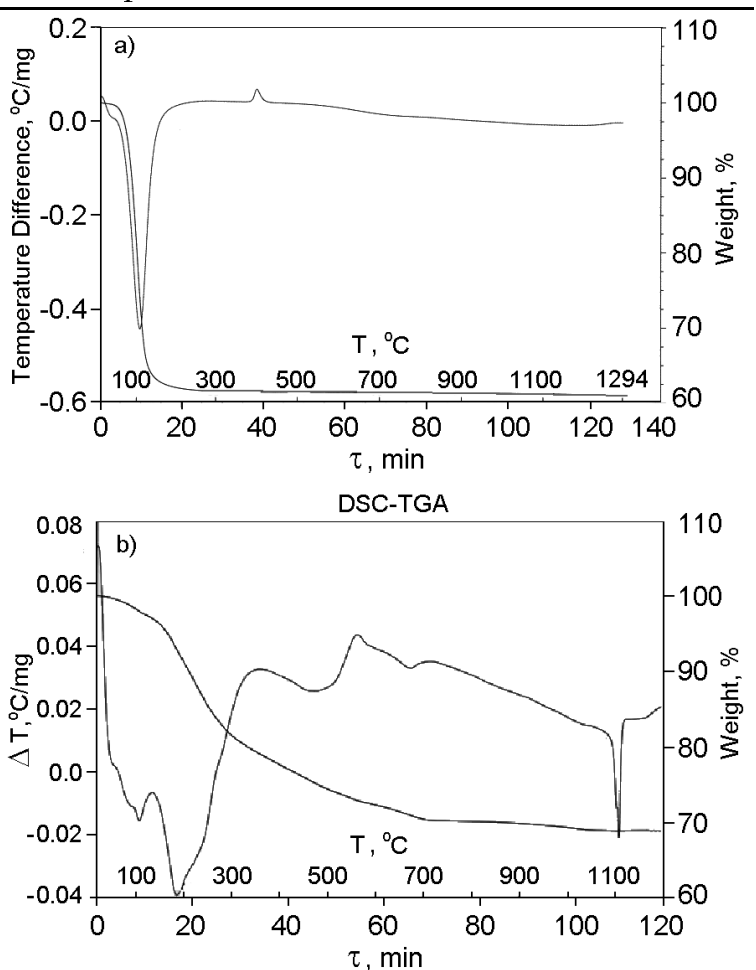

Fig. 2. DTA/TG analysis of the samples: $a-$ PMP, b - PMP + 10 wt \% CsCl.

10 wt. \% CsCl are shown in Table 1. From the presented data, it can be concluded that the thermal treatment at $700^{\circ} \mathrm{C}$ for $1 \mathrm{~h}$ does not lead to a decrease in the cesium amount in samples of PMP +10 wt. \% CsCl composition.

Isostatic treatment of PMP and PMP + 10 wt. $\% \mathrm{CsCl}$ samples was carried out on a laboratory gas-static unit GAUS-4/2000-35 at temperature of $900^{\circ} \mathrm{C}$ and pressures of 200 and $400 \mathrm{MPa}$ for 1 hour. Capsules with samples $50-60 \mathrm{~mm}$ in length and $10 \mathrm{~mm}$ in diameter were placed with special equipment in the working zone of the gas-stove oven. After HIP, the material was extracted from the steel shell mechanically and the composition, structure and properties of the obtained samples were studied (Fig. 3).

\section{Results and discussion}

After hot isostatic compaction at temperature of $900^{\circ} \mathrm{C}$ and pressure of $200 \mathrm{MPa}$ for $1 \mathrm{~h}$, lines of potassium-magnesium mo-

Table 1. Element composition of PMP +10 wt. $\% \mathrm{CsCl}$ samples after heat treatment

\begin{tabular}{|c|c|c|c|c|c|c|c|c|c|c|c|}
\hline \multirow{2}{*}{$\begin{array}{l}\text { Temperature, } \\
\text { time of heat } \\
\text { treatment }\end{array}$} & \multicolumn{11}{|c|}{ Element composition, wt. \% } \\
\hline & $\mathrm{K}$ & $\mathrm{Mg}$ & $P$ & $\mathrm{O}$ & Cs & $\mathrm{Cl}$ & $\mathrm{Na}$ & Al & $\mathrm{Si}$ & $\mathrm{Ca}$ & S \\
\hline $700^{\circ} \mathrm{C}, 1 \mathrm{~h}$ & 9.9 & 24.1 & 14.6 & 30.8 & 10.27 & 5.9 & 3.5 & 0.02 & 0.17 & 0.07 & 0.67 \\
\hline
\end{tabular}




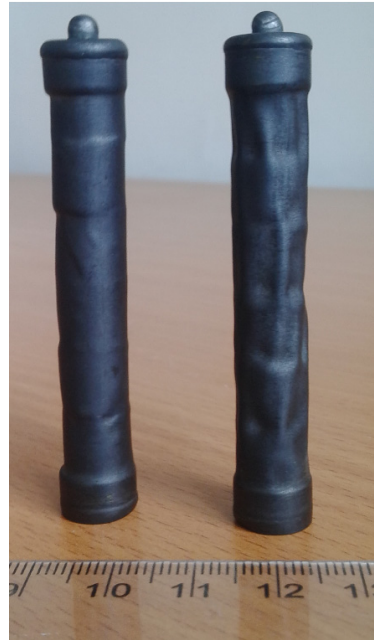

a)

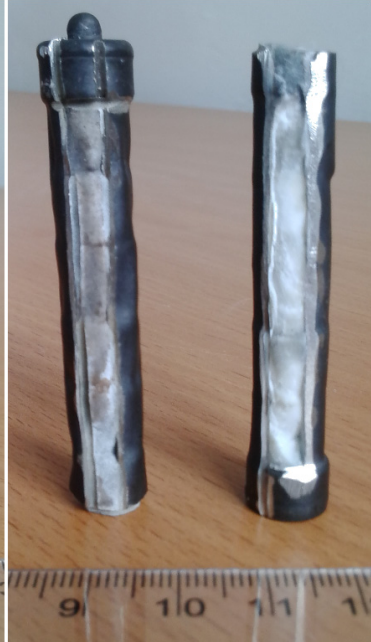

b)
Fig. 3. The view of capsules with PMP samples: a - after HIP, b - after extraction from the capsules shell.

nophosphate $\alpha-\mathrm{KMgPO}_{4}$ of a monoclinic structure (ASTM 089-4675) are observed on the X-ray diffraction pattern of the sample (Fig. 4a). With an increase in the pressure of the HIP up to $400 \mathrm{MPa}$ at a temperature of $900^{\circ} \mathrm{C}$, there were no polymorphic transformations in PMP sample (Fig. 4b). However, as follows from the analysis of the diffractograms, there are quite noticeable differences in the magnitudes of the intensities of reflections. Such changes in the intensity of the reflections, along with the small broadening, are apparently caused by the deformation of the PMP particles during the HIP processing, which is accompanied by the accumulation of linear defects.

The increase in the distortions of the crystal structure of the PMP samples with increasing of the HIP pressure is also indicated by the Raman spectrometry data (Fig. 5). The main lines of the Raman spectra of samples after HIP at the temperature of $900^{\circ} \mathrm{C}$ and pressure of $200 \mathrm{MPa}$ (Fig. 5a) are analogous to the previously published Raman spectra of $\mathrm{KMgPO}_{4}$ samples obtained by solid-phase synthesis at a temperature of $830^{\circ} \mathrm{C}$ for $10 \mathrm{~h}$. The highest intensity of the lines is observed at a Raman shift of 975 and $1000 \mathrm{~cm}^{-1}$, which corresponds to the vs $\left(\mathrm{PO}_{4}{ }^{3-}\right)$ oscillation lines in the potassiummagnesium phosphate spectrum of $\mathrm{KMgPO}_{4}$ [12]. With an increase in the HIP pressure up to $400 \mathrm{MPa}$ at the same temperature, the number of lines with a noticeable intensity of the Raman spectrum decreases sharply up to two lines: 956 and $981 \mathrm{~cm}^{-1}$ (Fig. 5b).

Photographs of the microstructure of samples of potassium-magnesium phosphate $\mathrm{KMgPO}_{4}$ obtained after hot isostatic pressing at a temperature of $900^{\circ} \mathrm{C}$ and a pressure of $200 \mathrm{MPa}$ and $400 \mathrm{MPa}$ for $1 \mathrm{~h}$ are shown in Fig. 6. The microstructures of the samples demonstrate the presence of generally well-faceted grains in PMP samples after HIP (pressure of 200 MPa, Fig. 6a) compared with the absence of a clear grain faceting in PMP samples after the HIP (pressure of $400 \mathrm{MPa}$, Fig. 6b). This is apparently due to the fact that at higher pressures, the grains are brought closer together and rearranged, leading to an increase in the intergrain contacts. This process, in turn, leads to an increase in mass transfer, change in the shape of the grains, and a more dense structure formation.

As can be seen from the PMP +10 wt. $\%$ $\mathrm{CsCl}$ diffractograms, the samples after HIP treatment at the temperature of $900^{\circ} \mathrm{C}$ (pressures of 200 and $400 \mathrm{MPa}$ ) consist of a single phase of $\mathrm{K}_{1-x} \mathrm{Cs}_{x} \mathrm{MgPO}_{4}$ (Fig. 7). As well as in the case of X-ray diffraction patterns of samples without cesium chloride additions, changes in the intensities of reflections are observed with an increase in pressure from 200 to $400 \mathrm{MPa}$. However,
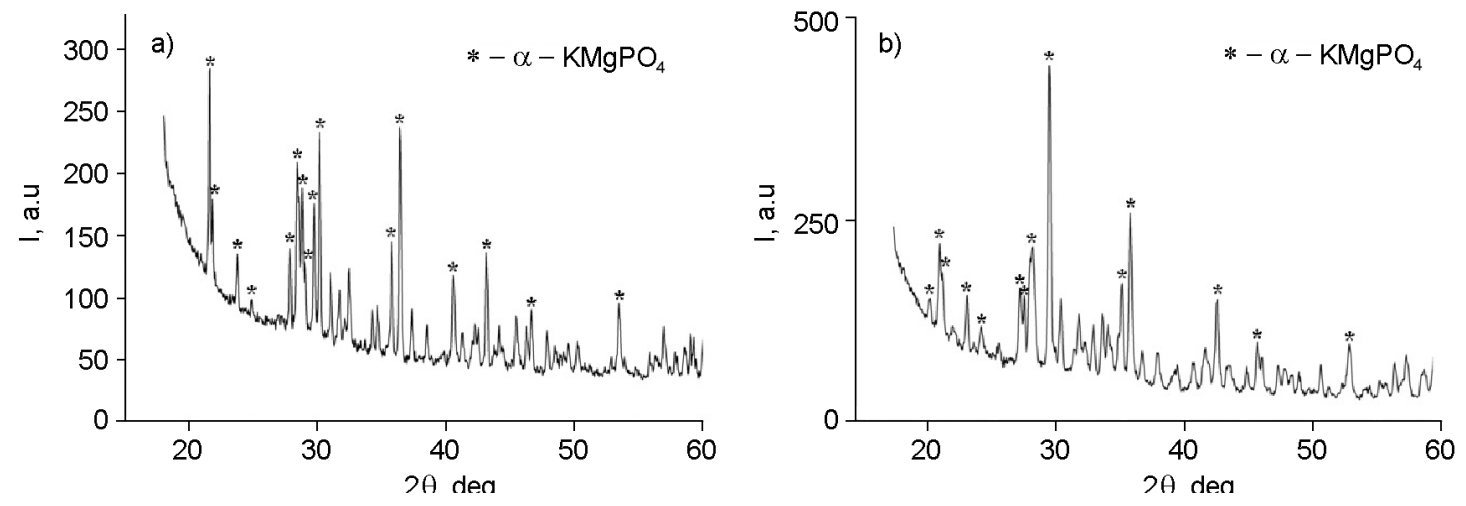

Fig. 4. XRD patterns of the PMP samples after HIP: a $-900^{\circ} \mathrm{C}, 200 \mathrm{MPa}, \mathrm{b}-900^{\circ} \mathrm{C}, 400 \mathrm{MPa}$. 

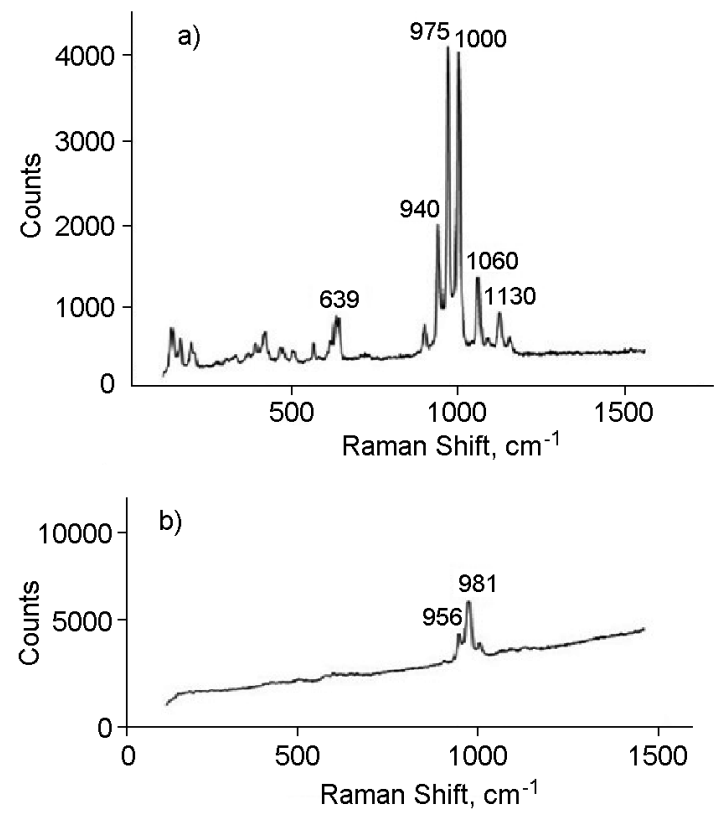

Fig. 5. Raman spectra of $\mathrm{KMgPO}_{4}$ samples after HIP: $\mathrm{a}-900^{\circ} \mathrm{C}, 200 \mathrm{MPa}, \mathrm{b}-900^{\circ} \mathrm{C}$, $400 \mathrm{MPa}$.

the presence of cesium leads to significant distortions in the crystal lattice of potassium-magnesium phosphate (Fig. 7b). There are also significant changes in the Raman spectra of PMP +10 wt. $\%$ CsCl samples with an increase in the HIP pressure from 200 to $400 \mathrm{MPa}$ (Fig. 8). The highest intensity of the lines of the Raman spectrum of samples after HIP at the temperature of $900^{\circ} \mathrm{C}$ and pressure of $200 \mathrm{MPa}$ is observed at a Raman shift of 982, 1011 and $1044 \mathrm{~cm}^{-1}$ (Fig. 8a). With an increase in the pressure, the Raman spectrum significantly changes: the Raman shift lines of 957 and $1064 \mathrm{~cm}^{-1}$ are characterized by the maximum intensity values (Fig. 8b).

The presence of cesium atoms in the lattice is evidenced by the fact that the lattice parameters $a$ and $b$ of PMP +10 wt. $\% \mathrm{CsCl}$ after the $\operatorname{HIP}\left(T=900^{\circ} \mathrm{C}, P=200 \mathrm{MPa}\right)$ increase in comparison with the $\alpha-\mathrm{KMgPO}_{4}$ single crystal lattice parameters. The $\alpha$ $\mathrm{KMgPO}_{4}$ single crystal lattice parameters data were obtained by the hydrothermal method under pressure $90 \mathrm{MPa}$ at a temperature of $500^{\circ} \mathrm{C}$ for 2 days (Table 2) [13]. With an increase in the HIP pressure up to $400 \mathrm{MPa}$, an insignificant increase in the parameters $a$ and $b$ and a more substantial increase in the $c$ lattice parameter of PMP +10 wt. $\% \mathrm{CsCl}$ were indicated.

The structure of PMP containing cesium after HIP is homogeneous and fine-crystalline (Fig. 9). As well as in the case of PMP

Table 2. Crystalline lattice parameters of the $\mathrm{KMgPO}_{4}+10$ wt. $\% \mathrm{CsCl}$ after $\mathrm{HIP}$

\begin{tabular}{|c|c|c|}
\hline Sample & Phase composition & Lattice parameters, $\AA$ \\
\hline $\begin{aligned} \mathrm{KMgPO}_{4}+ & 10 \text { wt. } \% \text { CsCl, HIP: } 900^{\circ} \mathrm{C}, \\
& 200 \mathrm{MPa}, 1 \text { hour }\end{aligned}$ & $\alpha-\mathrm{K}_{1-x} \mathrm{Cs}_{x} \mathrm{MgPO}_{4}$ & $\begin{aligned} a=8.594, & b=5.097, c=18,938, \\
\beta & =91.51^{\circ}\end{aligned}$ \\
\hline $\begin{array}{c}\mathrm{KMgPO}_{4}+10 \text { wt. } \% \mathrm{CsCl}, \mathrm{HIP}: 900^{\circ} \mathrm{C} \\
400 \mathrm{MPa}, 1 \text { hour }\end{array}$ & $\alpha-\mathrm{K}_{1-x} \mathrm{Cs}_{x} \mathrm{MgPO}_{4}$ & $\begin{aligned} a=8.602, & b=5.103, c=19.008, \\
\beta & =91.76^{\circ}\end{aligned}$ \\
\hline$\alpha-\mathrm{KMgPO}_{4} \begin{array}{c}\text { hydrothermal-grown single } \\
\text { crystal }\end{array}$ & $\alpha-\mathrm{KMgPO}_{4}$ & $\begin{array}{c}a=8.549(2), b=5.078(1), \\
c=18.996(2), \beta=91.68(1)[13]\end{array}$ \\
\hline
\end{tabular}

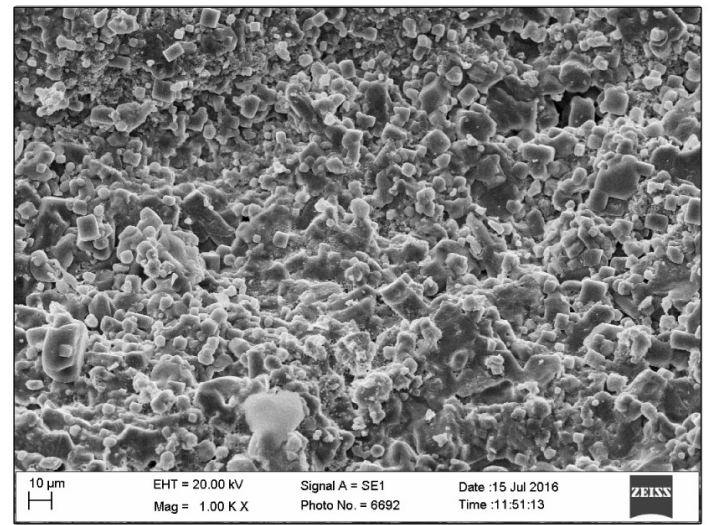

a)

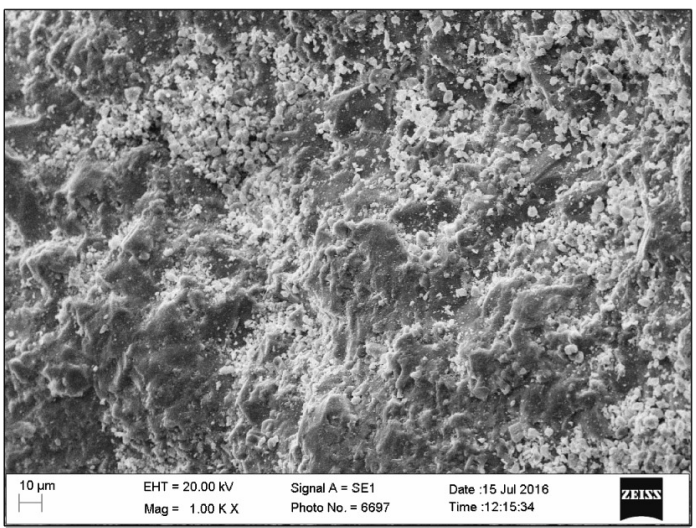

b)

Fig. 6. SEM images of $\mathrm{KMgPO}_{4}$ samples after $\mathrm{HIP}: \mathrm{a}-900^{\circ} \mathrm{C}, 200 \mathrm{MPa}, \mathrm{b}-900^{\circ} \mathrm{C}, 400 \mathrm{MPa}$. 

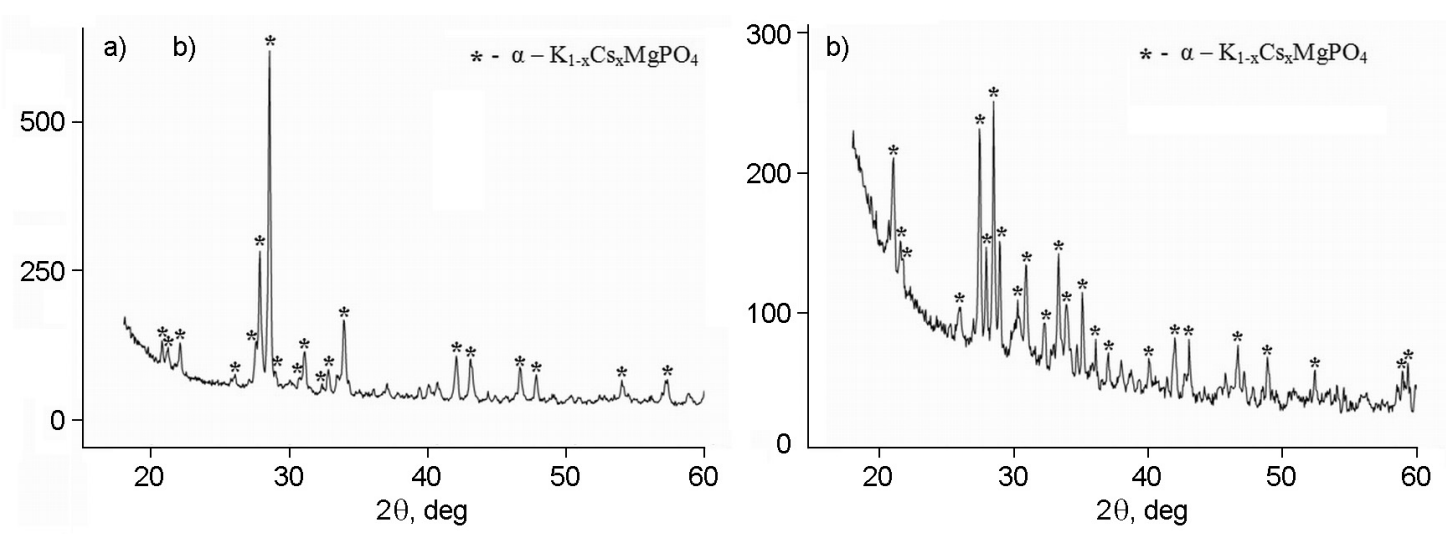

Fig. 7. Diffractograms of the PMP +10 wt. $\% \mathrm{CsCl}$ samples after $\mathrm{HIP}: \mathrm{a}-900^{\circ} \mathrm{C}, 200 \mathrm{MPa}, \mathrm{b}-$ $900^{\circ} \mathrm{C}, 400 \mathrm{MPa}$.

samples without the addition of $\mathrm{CsCl}$, a grains of the PMP +10 wt. $\% \mathrm{CsCl}$ samples after the $\operatorname{HIP}\left(T=900^{\circ} \mathrm{C}, \quad P=200 \mathrm{MPa}\right)$ have a clearer faceting than the grains of the PMP + 10 wt. \% CsCl samples after the HIP with pressure of $400 \mathrm{MPa}$. The grain size of the PMP +10 wt. $\% \mathrm{CsCl}$ samples after the $\operatorname{HIP}\left(T=900^{\circ} \mathrm{C}, P=200 \mathrm{MPa}\right)$ is advantageously $2-2.5 \mu \mathrm{m}$, although the presence of smaller and larger grains is noted. Increasing the pressure of the HIP up to $400 \mathrm{MPa}$ does not lead to a significant growth of the grains, and the average diameter is $2.5-3 \mu \mathrm{m}$. At the same time, denser packing of the grains with a rounded shape is observed after the $\operatorname{HIP}\left(T=900^{\circ} \mathrm{C}\right.$, $P=400 \mathrm{MPa}$, Fig. 9).

The increase in the relative density of the PMP samples was detected with an increase in the HIP pressure at $900^{\circ} \mathrm{C}$. The maximum is $99 \%$ of the theoretical value (Table 3) at the pressure of $400 \mathrm{MPa}$. It is known that the calculated density of monophosphate $\alpha-\mathrm{KMgPO}_{4}$ is $2.55 \mathrm{~g} / \mathrm{cm}^{3}$ [13]. For PMP +10 wt. $\%$ CsCl samples after HIP with a pressure of $200 \mathrm{MPa}$, an increase in the apparent density is observed compared with the PMP samples due to the presence of heavier cesium atoms. The decrease in the apparent density of PMP + 10 wt. \%. CsCl samples with an increase in the HIP pressure appears to be due to the presence of a small amount of chlorine magnesium phosphate $\mathrm{Mg}_{2} \mathrm{PO}_{4} \mathrm{Cl}$, which is dechlorinated, decomposed and formed additional pores at such HIP parameters $(T=$ $\left.900^{\circ} \mathrm{C}, P=400 \mathrm{MPa}\right)$.

Confirmation of the decrease in the apparent density of $\mathrm{PMP}+10$ wt. $\% \mathrm{CsCl}$ samples with an increase in the HIP pressure is given by $3 \mathrm{D}$ analysis data. In a single part $\left(V=222.7 \mathrm{~mm}^{3}\right)$ of PMP +10 wt. $\%$
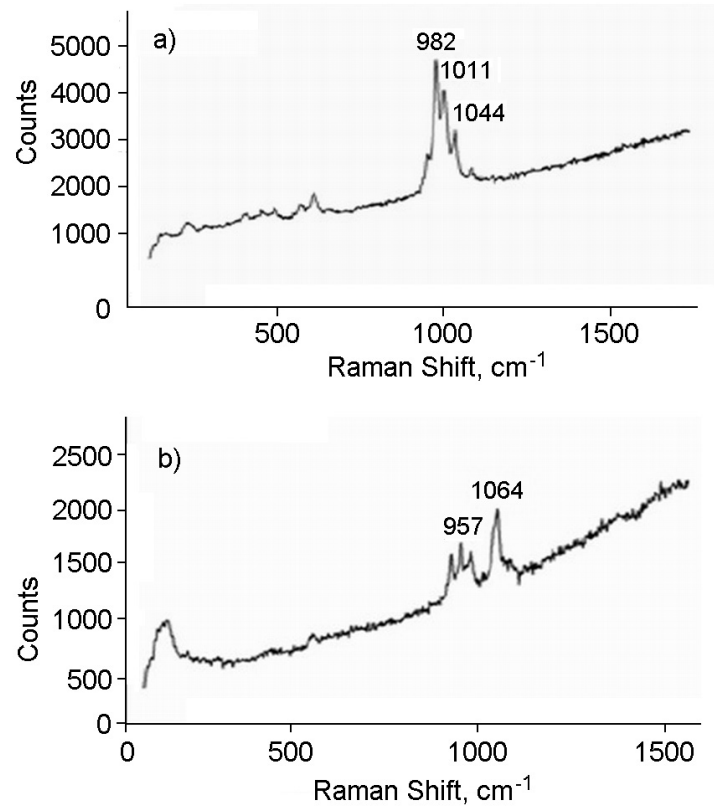

Fig. 8. Raman spectra of $\mathrm{KMgPO}_{4}+10 \mathrm{wt} \%$ $\mathrm{CsCl}$ samples after HIP: a $-900^{\circ} \mathrm{C}$,

Table 3. Dependences of apparent density of PMP and PMP + 10 wt. $\% \mathrm{CsCl}$ samples on the HIP pressure

\begin{tabular}{|c|c|c||}
\hline \multirow{2}{*}{ Sample } & \multicolumn{2}{|c|}{$\begin{array}{c}\text { Apparent density, } \\
\mathrm{g} / \mathrm{cm}^{3} \text { HIP, } 900^{\circ} \mathrm{C}, 1 \mathrm{~h}\end{array}$} \\
\cline { 2 - 3 } & $200 \mathrm{MPa}$ & $400 \mathrm{MPa}$ \\
\hline PMP & 2.38 & 2.52 \\
PMP + 10 wt. $\% \mathrm{CsCl}$ & 2.61 & 2.49 \\
\hline
\end{tabular}

$\mathrm{CsCl}$ sample obtained after $\operatorname{HIP}\left(T=900^{\circ} \mathrm{C}\right.$, $P=200 \mathrm{MPa}$ ) process 3 pores were detected: one large diameter $0.48 \mathrm{~mm}$ and two smaller with diameters of 0.15 and $0.1 \mathrm{~mm}$ (Fig. 10a). At the same time, larger pores with a diameter $>1 \mathrm{~mm}$ are present in PMP 


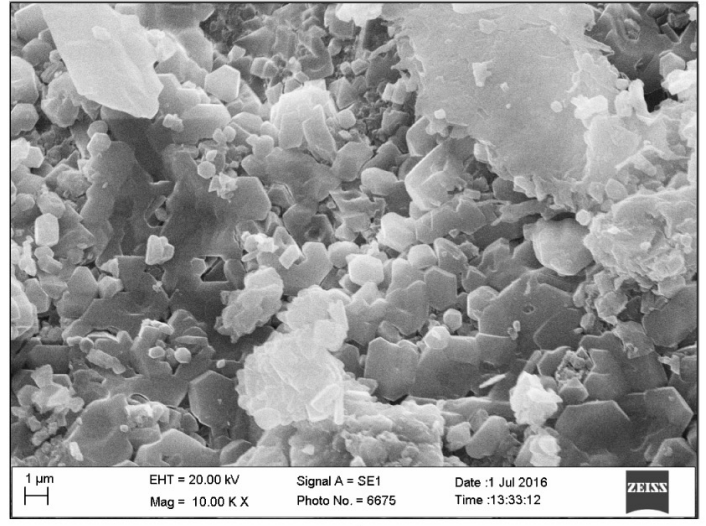

a)

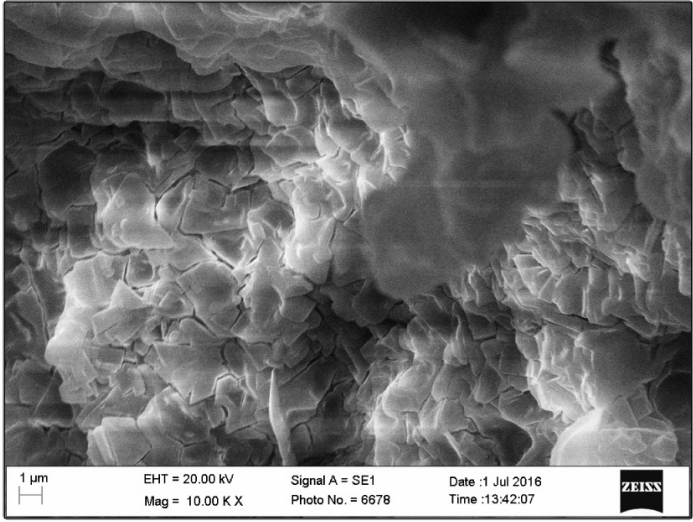

b)

Fig. 9. SEM images of $\mathrm{KMgPO}_{4}+10 \mathrm{wt} \% \mathrm{CsCl}$ samples after $\mathrm{HIP}: \mathrm{a}-900^{\circ} \mathrm{C}, 200 \mathrm{MPa}, \mathrm{b}-$ $900^{\circ} \mathrm{C}, 400 \mathrm{MPa}$.

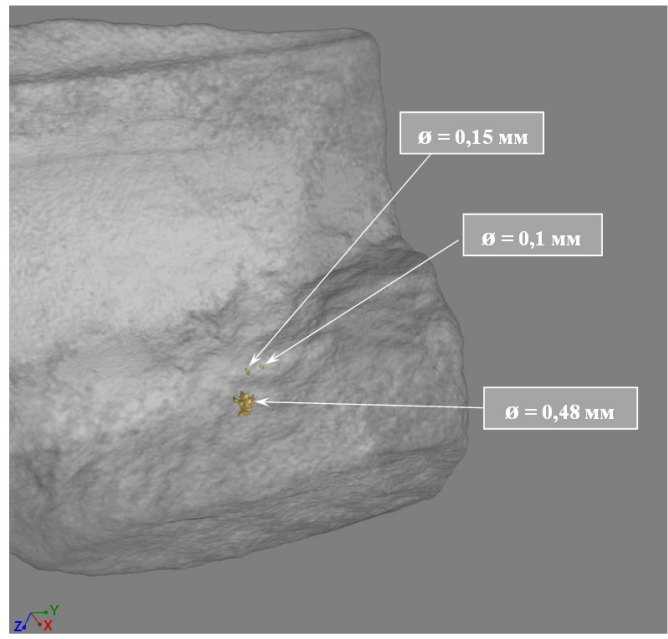

a)

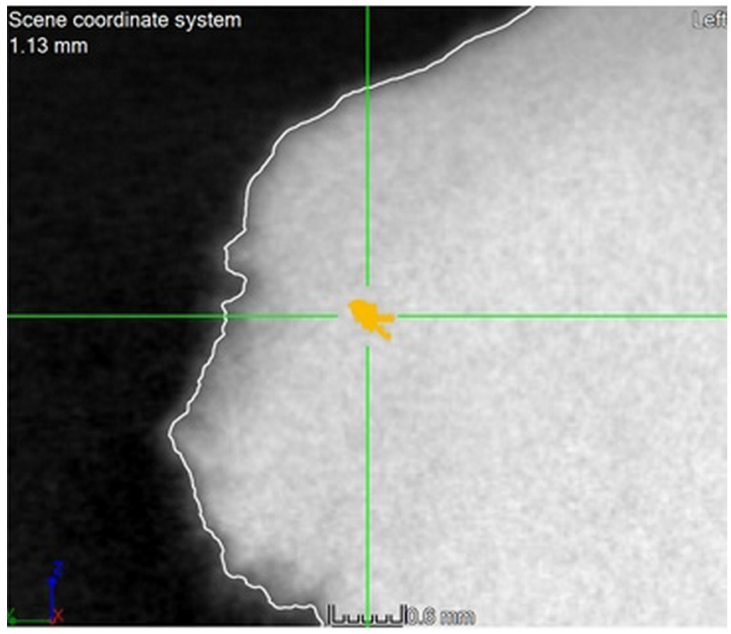

b)

Fig. 10. 3D images of $\mathrm{KMgPO}_{4}+10$ wt $\% \mathrm{CsCl}$ samples after $\mathrm{HIP}: \mathrm{a}-900^{\circ} \mathrm{C}, 200 \mathrm{MPa}, \mathrm{b}-$ $900^{\circ} \mathrm{C}, 400 \mathrm{MPa}$.

+10 wt. $\% \mathrm{CsCl}$ sample after $\operatorname{HIP}\left(T=900^{\circ} \mathrm{C}\right.$, $P=400 \mathrm{MPa}$ ) process (Fig. 10b).

The high-density samples of cesium-containing potassium-magnesium phosphate were produced by hot isostatic pressing at pressure of $200 \mathrm{MPa}$, temperature of $900^{\circ} \mathrm{C}$ and holding time of $1 \mathrm{~h}$. The development of manufacturing methods and new materials capable for cesium retaining is challenging after the nuclear accident at the Fukushima nuclear power plant. ${ }^{137} \mathrm{Cs}$, characterized by high activity, high solubility and leaching rate, is one of the main heat-generating isotopes in radioactively contaminated wastewaters. Recently, a large number of materials have been proposed which are capable of efficiently recovering, and then, in the cured form, retaining readily volatile cesium $[14,15]$. The presented results on the production of high-density potassium-magnesium-phosphate materials containing cesium can be useful for the further development of materials and methods of radioactive cesium reliable isolation.

\section{Conclusions}

High-density samples of potassium-magnesium phosphate and potassium-magnesium phosphate with cesium were produced by hot isostatic pressing method. The obtained materials have monophase monoclinic structure of potassium-magnesium monophosphate $\alpha-\mathrm{KMgPO}_{4}$.

Ceramic PMP and PMP +10 wt. $\% \mathrm{CsCl}$ samples after hot isostatic pressing demonstrate a homogeneous fine-crystalline structure. The maximum apparent density of PMP samples after HIP at the pressure of $400 \mathrm{MPa}$, temperature of $900^{\circ} \mathrm{C}$ and holding time of $1 \mathrm{~h}$ was $2.52 \mathrm{~g} / \mathrm{cm}^{3}$, and PMP + 10 wt. $\% \mathrm{CsCl}$ samples after HIP at a pres- 
sure of $200 \mathrm{MPa}, 900^{\circ} \mathrm{C}$ and holding time $1 \mathrm{~h}-2.61 \mathrm{~g} / \mathrm{cm}^{3}$.

The obtained high-density ceramic potassium-magnesium-phosphate materials are promising for use as a material for medical cesium sources of $\gamma$ radiation and for immobilization of radioactive cesium.

\section{References}

1. V.M.Azhazha, V.A.Belous, S.Yu.Sayenko et al., Nuclear Energy. Handling of Spent Nuclear Fuel and Radioactive Waste, Review of the Materials of Foreign and Domestic Press, ed. by I.M.Neklyudova, Naukova Dumka, Kiev (2006) [in Russian].

2. A.O.Merkushkin, The Thesis for the Degree of Candidate of Chemical Sciences, Moscow (2003).

3. V.L.Balkevich, Technical Ceramics, Stroyizdat, Moscow (1984) [in Russian].

4. A.P.Shpak, V.L.Karbovskiy, V.V.Trachevskiy, Apatity, Akademperiodika, Kiev (2002) [in Russian].

5. E.R.Vance, J.Davis, K.Olufson et al., J. Nucl. Mater., 420, 396 (2012).
6. S.Yu.Sayenko, Nucl. Radiat. Safety, 1, 41 (2015).

7. A.S.Wagh, Chemically Bonded Phosphate Ceramics, Twenty-First Century Materials with Diverse Application, Second Edition, Elsevier Ltd (2016).

8. S.E.Vinokurov, Y.M.Kulyako, O.M.Slyuntchev et al., J. Nucl. Mater., 385, 189 (2009).

9. D.Singh, V.R.Mandalika, S.J.Parulekar, A.S.Wagh, J. Nucl. Mater., 348, 272 (2006).

10. A.S.Wagh, S.Y.Sayenko, V.A.Shkuropatenko et al., J. Hazard. Mater., 302, 241 (2016).

11. Siyu Zhang, Hui-Sheng, Shao-Wen Huang, Ping Zhang, J.Therm. Anal.Calorim., 111, 35 (2013).

12. L.Miladi, A.Oueslati, K.Guidara, RSC (Royal Soc. Chem.) Adv., 6, 83280 (2016).

13. G.Wallez, C.Colbeau-Justin, T.Le Mercier et al., J. Solid State Chem., 136, 175 (1998).

14. Yoshinobu Yokomori, Kazuhito Asazuki, Natsumi Kamiya et al., Sci. Reports, 4, 4195 (2014).

15. Xiaoxia Zhang, Yan Wu, Yuezhou Wei et al., J. Nucl. Mater., 485, 39 (2017). 